\title{
Spongiibacter tropicus sp. nov., isolated from a Synechococcus culture
}

\begin{abstract}
Correspondence
Byung Cheol Cho

bccho@snu.ac.kr
\end{abstract}

\section{Chung Yeon Hwang and Byung Cheol Cho}

School of Earth and Environmental Sciences and Research Institute of Oceanography, Seoul National University, San 56-1, Shillim-dong, Kwanak-gu, Seoul 151-742, Republic of Korea
Two Gram-staining-negative, rod-shaped and non-motile strains, designated CL-CB221 ${ }^{\top}$ and CL-CB467, were isolated from a Synechococcus culture derived from tropical surface water of the Pacific Ocean. The 16S rRNA gene sequences of the two strains were identical, and it was found that they belonged to the class Gammaproteobacteria, with Spongiibacter marinus $\mathrm{HAL} 40 \mathrm{~b}^{\top}$ as their closest relative (similarity of $96.3 \%$ ). Both strains grew optimally at $30-35{ }^{\circ} \mathrm{C}$ and $\mathrm{pH} 7-8$ in the presence of 3-4\% $(\mathrm{w} / \mathrm{v}) \mathrm{NaCl}$. The major cellular fatty acids were $\mathrm{C}_{18: 1} \omega 7 \mathrm{c}$, $\mathrm{C}_{17: 1} \omega 8 c, \mathrm{C}_{16: 0}$ and summed feature $3\left(\mathrm{C}_{16: 1} \omega 7 c\right.$ and/or iso- $\left.\mathrm{C}_{15: 0} 2-\mathrm{OH}\right)$. The genomic DNA $\mathrm{G}+\mathrm{C}$ contents were 57.7 and $57.8 \mathrm{~mol} \%$, respectively. DNA-DNA hybridization experiments revealed high values ( $97 \pm 2 \%)$ for relatedness between strains CL-CB221 ${ }^{\top}$ and CL-CB467, which suggested that these two strains belong to a single species. Based on the phylogenetic, chemotaxonomic and phenotypic data presented, it is proposed that strains CL-CB221 ${ }^{\top}$ and CLCB467 represent a novel species of the genus Spongiibacter, for which the name Spongiibacter

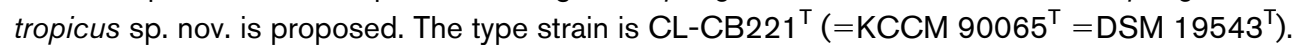

The genus Spongiibacter was established by Graeber et al. (2008) with Spongiibacter marinus as the type species for a motile marine bacterium that was isolated from a boreal sponge and required $\mathrm{NaCl}$ for growth $(1-7 \%$, w/v). At the time of publication, Spongiibacter marinus $\mathrm{HAL}_{40 \mathrm{~b}}{ }^{\mathrm{T}}$ was found to be phylogenetically distantly related to the genera Neptunomonas and Marinobacter in the class Gammaproteobacteria with low $16 \mathrm{~S}$ rRNA gene sequence similarities (about $90 \%)$. The major fatty acids $\left(\mathrm{C}_{17: 1} \omega 8\right.$, $\mathrm{C}_{17: 0}$ and $\left.\mathrm{C}_{18: 1} \omega 7\right)$ of Spongiibacter marinus HAL40b ${ }^{\mathrm{T}}$ supported the proposal of a novel species within a novel genus (Graeber et al., 2008). In this study, two strains isolated from a Synechococcus culture were subjected to a polyphasic taxonomic analysis and allocated to the genus Spongiibacter.

A Synechococcus culture was derived from tropical surface water of the Pacific Ocean and maintained by transferring a small quantity of the culture to $\mathrm{f} / 2$ medium (Guillard \& Ryther, 1962) supplemented with ammonium chloride (final concentration $100 \mu \mathrm{M}$ ). The culture was incubated at $25{ }^{\circ} \mathrm{C}$ under approx. $20 \mu \mathrm{E} \mathrm{m}^{-2} \mathrm{~s}^{-1}$ (a $14 \mathrm{~h} \mathrm{light} / 10 \mathrm{~h}$ dark cycle). To isolate bacteria in the Synechococcus culture, an aliquot $(30 \mu \mathrm{l})$ of the culture in the exponential growth phase was spread on a marine agar 2216 (MA; Difco) plate,

The GenBank/EMBL/DDBJ accession numbers for the 16S rRNA gene sequences of strains $\mathrm{CL}-\mathrm{CB} 221^{\top}$ and $\mathrm{CL}-\mathrm{CB} 467$ are respectively EF988653 and EF988654.

A supplementary table showing cellular fatty acid compositions is available with the online version of this paper. and the plate was aerobically incubated at $25{ }^{\circ} \mathrm{C}$ for 1 week. Strains CL-CB22 $1^{\mathrm{T}}$ and CL-CB467 were isolated and subsequently streaked onto fresh MA plates. The purification procedure was repeated four times. The strains were maintained on MA at $4{ }^{\circ} \mathrm{C}$ and preserved in marine broth 2216 (MB; Difco) supplemented with $30 \%$ (v/v) glycerol at $-80{ }^{\circ} \mathrm{C}$.

For 16S rRNA gene sequence amplification by PCR, DNA was extracted from single colonies by a boiling method (Englen \& Kelley, 2000) and the crude extract served as the template for amplification with Taq DNA polymerase (Bioneer) and primers 27F and 1492R (Lane, 1991). PCR products were purified with the AccuPrep PCR purification kit (Bioneer) and direct sequence determination was performed with an automated sequencer (ABI 3730xl; Applied Biosystems) at Macrogen (Seoul, Korea). The almost-complete 16S rRNA gene sequences of strains CL$\mathrm{CB} 221^{\mathrm{T}}$ (1406 bp) and CL-CB467 (1409 bp) were obtained and compared with available $16 \mathrm{~S}$ rRNA gene sequences in GenBank using BLASTN searches (Altschul et al., 1990). The sequences were manually aligned with those of related species in the class Gammaproteobacteria, obtained from the GenBank and Ribosomal Database Project II (Cole et al., 2007) databases, using known 16S rRNA secondarystructure information. Phylogenetic trees were obtained by use of neighbour-joining (Saitou \& Nei, 1987), maximumparsimony (Fitch, 1971) and maximum-likelihood (Felsenstein, 1981) methods. An evolutionary distance matrix for the neighbour-joining method was generated according to the model of Jukes \& Cantor (1969). The 
robustness of tree topologies was assessed by bootstrap analyses based on 1000 replications for the neighbourjoining and the maximum-parsimony methods and 100 replications for the maximum-likelihood method. Alignment analysis was carried out using the jPHYDIT program (Jeon et al., 2005), and phylogenetic analyses were carried out using MEGA 4 (Tamura et al., 2007) and PAUP 4.0 (Swofford, 1998). Likelihood parameters were estimated by using hierarchical ratio test in MODELTEST version 3.04 (Posada \& Crandall, 1998).

Morphological and physiological tests were performed as follows. Gram-staining was performed as described by Smibert \& Krieg (1994). Unless otherwise specified, all biochemical characteristics of strains CL-CB22 $1^{\mathrm{T}}$ and CLCB467 and Spongiibacter marinus HAL40b ${ }^{\mathrm{T}}$ were determined using cultures grown on MA at $30{ }^{\circ} \mathrm{C}$. Motility of the cells was assessed by the hanging-drop method (Skerman, 1967) with cells grown in MB for 3 days. Cellular morphology and the presence of flagella were observed using transmission electron microscopy (EX2; JEOL). Anaerobic growth was checked on MA and ZOF medium (Lemos et al., 1985) supplemented with agar $(1.5 \%)$ by using the GasPak anaerobic system (BBL) at $30{ }^{\circ} \mathrm{C}$ for 15 days. The temperature range for growth was examined on the basis of colony formation on MA incubated at temperatures ranging from 5 to $45^{\circ} \mathrm{C}$ (in increments of $5{ }^{\circ} \mathrm{C}$ ). The $\mathrm{pH}$ range for growth was determined by assessing changes in $\mathrm{OD}_{600}$ in $\mathrm{pH}$-buffered $\mathrm{MB}$ (pH 5-11, in increments of $1 \mathrm{pH}$ unit) (Manaia et al., 2003; Yumoto et al., 2004) at $30{ }^{\circ} \mathrm{C}$ for up to 7 days. The tolerance of strains CL-CB221 ${ }^{\mathrm{T}}$ and CL-CB467 to $\mathrm{NaCl}$ was determined by assessing changes in $\mathrm{OD}_{600}$ in synthetic ZoBell broth ( $1^{-1}$ distilled water: $5 \mathrm{~g}$ Bacto peptone; $1 \mathrm{~g}$ yeast extract; $0.1 \mathrm{~g}$ ferric citrate) with $0-10 \%$ (in increments of $1 \%$ ) and $15 \% \mathrm{NaCl}$ at $30{ }^{\circ} \mathrm{C}$.

Oxidase and catalase tests were performed according to the protocols described by Smibert \& Krieg (1994). Hydrolysis of DNA, gelatin, starch and Tweens 40 and 80, ornithine and lysine deaminase activities and Voges-Proskauer and methyl red tests were determined according to Hansen \& Sørheim (1991). $\mathrm{H}_{2} \mathrm{~S}$ production was tested as described by Bruns et al. (2001). In addition, other enzyme activities were assayed in duplicate using the API ZYM and API 20NE kits (bioMérieux) according to the manufacturer's instructions except that the cell suspension was prepared using artificial seawater $\left(1^{-1}\right.$ distilled water: $24 \mathrm{~g} \mathrm{NaCl}$; $10.9 \mathrm{~g} \mathrm{MgCl}_{2} .6 \mathrm{H}_{2} \mathrm{O} ; 4 \mathrm{~g} \mathrm{Na}_{2} \mathrm{SO}_{4} ; 1.5 \mathrm{~g} \mathrm{CaCl}_{2} .2 \mathrm{H}_{2} \mathrm{O} ; 0.7 \mathrm{~g}$ $\mathrm{KCl} ; 0.2 \mathrm{~g} \mathrm{NaHCO}$; $0.1 \mathrm{~g} \mathrm{KBr} ; 0.027 \mathrm{~g} \mathrm{H}_{3} \mathrm{BO}_{3} ; 0.03 \mathrm{~g}$ $\mathrm{SrCl}_{2} .6 \mathrm{H}_{2} \mathrm{O} ; 0.003 \mathrm{~g} \mathrm{NaF}$; Lyman \& Fleming, 1940). Carbon utilization was tested using the basal broth medium supplemented with yeast extract $\left(1^{-1}\right.$ distilled water: $23.6 \mathrm{~g} \mathrm{NaCl} ; 0.64 \mathrm{~g} \mathrm{KCl} ; 4.53 \mathrm{~g} \mathrm{MgCl}_{2} .6 \mathrm{H}_{2} \mathrm{O}$; $5.94 \mathrm{~g} \mathrm{MgSO}_{4} .7 \mathrm{H}_{2} \mathrm{O} ; 1.3 \mathrm{~g} \mathrm{CaCl}_{2} .2 \mathrm{H}_{2} \mathrm{O} ; 0.2 \mathrm{~g} \mathrm{NaNO}_{3}$; $0.2 \mathrm{~g} \mathrm{NH}_{4} \mathrm{Cl} ; 0.05 \mathrm{~g}$ yeast extract; Bruns et al., 2001) containing $0.4 \%$ carbon source. Growth was monitored by $\mathrm{OD}_{600}$ using a spectrophotometer (Ultraspec 2000; Pharmacia Biotech). $\mathrm{OD}_{600}$ was measured every week for about 1 month. Carbon utilization was scored as negative when the growth rate was equal to or less than that in the negative control with no carbon source.

Fatty acid methyl esters in whole cells of strains CL-CB221 ${ }^{\mathrm{T}}$ and CL-CB467 and Spongiibacter marinus HAL40b ${ }^{\mathrm{T}}$ grown on MA at $30{ }^{\circ} \mathrm{C}$ for 3 days were analysed by gas chromatography according to the instructions of the Microbial Identification System (MIDI) at the Korean Culture Center of Microorganisms (Seoul, Korea). Genomic DNA of strains CL-CB22 $1^{\mathrm{T}}$ and CL-CB467 and Spongiibacter marinus

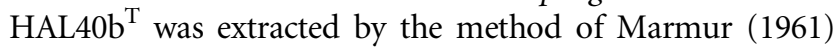
and $\mathrm{G}+\mathrm{C}$ contents were determined by HPLC (HP 100; Hewlett Packard) of deoxyribonucleosides as described by Mesbah et al. (1989). Lambda phage DNA was used as a standard and the genomic DNA of Salinisphaera shabanensis E1L3A ${ }^{\mathrm{T}}$ (62 mol\%; Antunes et al., 2003) and Maribacter arcticus KOPRI $20941^{\mathrm{T}}$ (36 mol\%; Cho et al., 2008) was used as references. The relatedness of genomic DNA between strains CL-CB221 ${ }^{\mathrm{T}}$ and CL-CB467 was determined by dotblot hybridization as described by Choi et al. (2006). The experiment was repeated on different days.

The 16S rRNA gene sequences of strains CL-CB221 ${ }^{\mathrm{T}}$ and CL-CB467 were identical. Phylogenetic analyses based on the 16S rRNA gene sequence showed that both strains belonged to the class Gammaproteobacteria (Fig. 1). They were most closely related to Spongiibacter marinus HAL40b ${ }^{\mathrm{T}}$, with $96.3 \%$ similarity, and no other species in the class Gammaproteobacteria shared more than $92 \%$ sequence similarity with the isolates. The tree topologies inferred from three tree-making algorithms showed that strains CL-CB22 $1^{\mathrm{T}}$ and CL-CB467 formed a robust cluster with the genus Spongiibacter (Fig. 1). This grouping was supported by high bootstrap values (neighbour-joining, $100 \%$; maximum-parsimony and maximum-likelihood, $99 \%)$. Thus, it is clear that our isolates belong to the genus Spongiibacter. However, the low similarity value $(96.3 \%)$ between the 16S rRNA gene sequences of the two isolates and Spongiibacter marinus $\mathrm{HAL} 40 \mathrm{~b}^{\mathrm{T}}$ indicated that strains CL-CB22 $1^{\mathrm{T}}$ and CL-CB467 represent a novel species in the genus (Rosselló-Mora \& Amann, 2001).

Strains CL-CB221 ${ }^{\mathrm{T}}$ and CL-CB467 gave identical results for morphological, physiological and biochemical characteristics (except for the utilization of succinate as a sole carbon source) and the results are given in the species description and Table 1. The genomic DNA G $+\mathrm{C}$ contents were 57.7 and $57.8 \mathrm{~mol} \%$, respectively. DNA-DNA hybridization experiments revealed high values $(97 \pm 2 \%)$ for relatedness between strains CL-CB22 ${ }^{\mathrm{T}}$ and CL-CB467. DNA-DNA hybridization, phenotypic and chemotaxonomic characteristics revealed that they belonged to the same species. The fatty acid profiles were generally similar between the two strains (Supplementary Table S1, available in IJSEM Online); dominant fatty acids for the strains were $\mathrm{C}_{18: 1} \omega 7 c(27.3-31.5 \%)$, followed by $\mathrm{C}_{17: 1} \omega 8 c$ (14.3$15.3 \%), \mathrm{C}_{16: 0}(12.9-14.4 \%)$ and summed feature 3 $\left(\mathrm{C}_{16: 1} \omega 7 c\right.$ and/or iso- $\left.\mathrm{C}_{15: 0} 2-\mathrm{OH} ; 11.4-16.2 \%\right)$. 


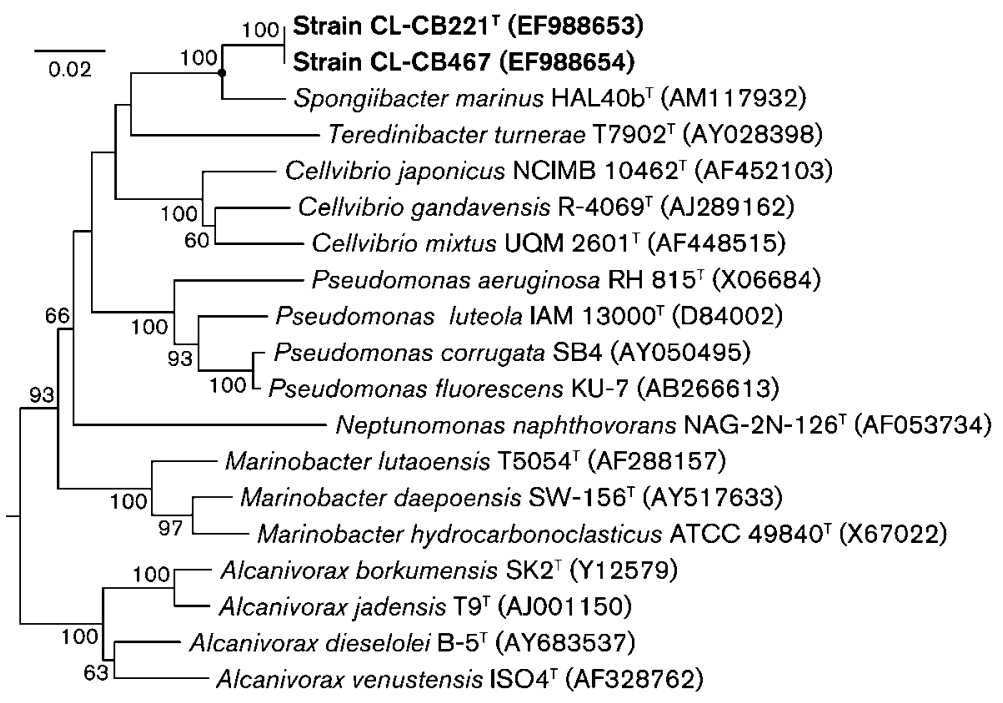

Fig. 1. Neighbour-joining tree derived from 16S rRNA gene sequences for strains CL$\mathrm{CB} 221^{\top}$ and CL-CB467 and related members in the class Gammaproteobacteria. The sequence of Thermotoga maritima $\mathrm{MSB}^{\top}$ (GenBank accession no. M21774) was used as the outgroup (not shown). Bootstrap values $(\geqslant 60 \%)$ based on 1000 resamplings are shown as percentages at branch nodes. The solid circle indicates that the corresponding node was also recovered in the maximumparsimony and maximum-likelihood trees. Bar, 0.02 substitutions per nucleotide position.

Certain chemotaxonomic and phenotypic characteristics can differentiate strains CL-CB22 $1^{\mathrm{T}}$ and CL-CB467 from the phylogenetically closest species, Spongiibacter marinus: the ability of the former strains to utilize pyruvate as a sole carbon source and inability to produce $N$-acetyl- $\beta$ glucosaminidase, leucine arylamidase and lipase (C14), to hydrolyse Tween 40 and to utilize arabinose (Table 1).

Overall, the phylogenetic, chemotaxonomic and phenotypic data obtained in this study indicate that strains CL$\mathrm{CB} 221^{\mathrm{T}}$ and CL-CB467 should be assigned to a novel species in the genus Spongiibacter, for which the name Spongiibacter tropicus sp. nov. is proposed.

\section{Description of Spongiibacter tropicus sp. nov.}

Spongiibacter tropicus [tro'pi.cus. L. masc. adj. tropicus tropical, of or pertaining to the tropic(s), relating to its isolation from a tropical ocean].

Gram-staining-negative, strictly aerobic, non-motile, rods approximately $0.4-0.5 \mu \mathrm{m}$ wide and $0.9-2.0 \mu \mathrm{m}$ long. After 5 days on marine agar plates at $30{ }^{\circ} \mathrm{C}$, colonies are creamy, circular and convex, and approximately $1 \mathrm{~mm}$ in diameter. Grows at $10-40{ }^{\circ} \mathrm{C}$ (optimum $30-35{ }^{\circ} \mathrm{C}$ ), pH 6-10 (optimum $\mathrm{pH} 7-8$ ) and with 1-9\% (w/v) $\mathrm{NaCl}$ (optimum $3-4 \%$ ). Positive for oxidase and catalase. Negative for ornithine and lysine deaminase activities, Voges-Proskauer and methyl red tests. Tween 80 is hydrolysed, but DNA, gelatin, starch and Tween 40 are not. $\mathrm{H}_{2} \mathrm{~S}$ is not produced. According to API ZYM, positive for acid and alkaline phosphatases, esterase (C4), esterase lipase (C8) and naphthol-AS-BI-phosphohydrolase, but negative for $\mathrm{N}$ acetyl- $\beta$-glucosaminidase, $\alpha$-chymotrypsin, cystine arylamidase, $\alpha$-fucosidase, $\alpha$ - and $\beta$-galactosidases, $\alpha$ - and $\beta$ glucosidases, $\beta$-glucuronidase, leucine arylamidase, lipase (C14), $\alpha$-mannosidase, trypsin and valine arylamidase. According to API 20NE, positive for aesculin hydrolysis, but negative for arginine dihydrolase, $\beta$-galactosidase
Table 1. Selected characteristics that differentiate strains CLCB22 $1^{\top}$ and CL-CB467 from Spongiibacter marinus $\mathrm{HAL} \mathrm{Ob}^{\top}$

Data were taken from this study and Graeber et al. (2008). Congruent results were obtained for strains CL-CB221 ${ }^{\mathrm{T}}$ and CL-CB467 unless stated. +, Positive; w, weak; - , negative.

\begin{tabular}{|c|c|c|}
\hline Characteristic & CL-CB221 ${ }^{\mathrm{T}}$ & $\begin{array}{c}\text { Spongiibacter } \\
\text { marinus } \text { HAL40b }\end{array}$ \\
\hline Isolation source & $\begin{array}{l}\text { Synechococcus } \\
\text { culture }\end{array}$ & Marine sponge \\
\hline $\begin{array}{l}\text { Cell size (width } \times \text { length }) \\
(\mu \mathrm{m})\end{array}$ & $\begin{array}{r}0.4-0.5 \times \\
0.9-2.0\end{array}$ & $0.4-0.6 \times 1-2$ \\
\hline Motility & - & + \\
\hline \multicolumn{3}{|l|}{ Conditions for growth } \\
\hline $\begin{array}{l}\text { Temperature [optimum] } \\
\left({ }^{\circ} \mathrm{C}\right)\end{array}$ & $10-40[30-35]$ & $10-40[20-30]$ \\
\hline $\mathrm{pH}$ [optimum] & $6-10[7-8]$ & $6.5-9.5[7-9]$ \\
\hline $\begin{array}{l}\mathrm{NaCl} \text { tolerance [optimum] } \\
(\%)\end{array}$ & $1-9[3-4]$ & $1-7[3]$ \\
\hline Hydrolysis of Tween 40 & - & + \\
\hline \multicolumn{3}{|l|}{ API ZYM tests } \\
\hline$N$-Acetyl- $\beta$-glucosaminidase & - & + \\
\hline Leucine arylamidase & - & + \\
\hline Lipase (C14) & - & $+^{*}$ \\
\hline \multicolumn{3}{|l|}{ Utilization of: } \\
\hline Arabinose & - & + \\
\hline Pyruvate & + & - \\
\hline Succinate & $-(w) \dagger$ & - \\
\hline DNA G $+\mathrm{C}$ content $(\mathrm{mol} \%)$ & $57.7(57.8) \dagger$ & 69.1末 \\
\hline
\end{tabular}

${ }^{\star}$ From this study.

$\dagger$ Result for strain CL-CB467 in parentheses.

$\ddagger$ Data from Graeber et al. (2008); a value of $60.6 \mathrm{~mol} \%$ was obtained in this study. 
(PNPG) and gelatinase, glucose fermentation, indole production, nitrate reductase and urease. Pyruvate is utilized as a sole carbon source, but acetate, arabinose, Larginine, cellobiose, citrate, D-fructose, D-galactose, Dglucose, glycerol, myo-inositol, lactose, mannitol, D-mannose, L-ornithine, L-rhamnose, D-salicin, sorbitol, succinate (weak in strain CL-CB467) and xylose are not utilized. The major cellular fatty acids are $\mathrm{C}_{18: 1} \omega 7 c, \mathrm{C}_{17: 1} \omega 8 c, \mathrm{C}_{16: 0}$ and summed feature $3\left(\mathrm{C}_{16: 1} \omega 7 c\right.$ and/or iso- $\left.\mathrm{C}_{15: 0} 2-\mathrm{OH}\right)$. The DNA $\mathrm{G}+\mathrm{C}$ content of the two known strains is 57.7$57.8 \mathrm{~mol} \%$.

The type strain is CL-CB22 $1^{\mathrm{T}}\left(=\mathrm{KCCM} 90065^{\mathrm{T}}=\mathrm{DSM}\right.$ $19543^{\mathrm{T}}$ ), isolated from a Synechococcus culture. Strain CLCB467 is a second strain of the species.

\section{Acknowledgements}

We acknowledge the expert technical support of Ms In-Sung Lee (electron microscopy) of the National Center for Inter-University Research Facilities at Seoul National University. This work was supported in part by the BK21 project of the Korean Government and the Ministry of Maritime Affairs and Fisheries (the Korea EAST-1 programme).

\section{References}

Altschul, S. F., Gish, W., Miller, W., Myers, E. W. \& Lipman, D. J. (1990). Basic local alignment search tool. J Mol Biol 215, 403-410.

Antunes, A., Eder, W., Fareleira, P., Santos, H. \& Huber, R. (2003). Salinisphaera shabanensis gen. nov., sp. nov., a novel, moderately halopholic bacterium from the brine-seawater interface of the Shaban Deep, Red Sea. Extremophiles 7, 29-34.

Bruns, A., Rohde, M. \& Berthe-Corti, L. (2001). Muricauda ruestringensis gen. nov., sp. nov., a facultatively anaerobic, appendaged bacterium from German North Sea intertidal sediment. Int $J$ Syst Evol Microbiol 51, 1997-2006.

Cho, K. H., Hong, S. G., Cho, H. H., Lee, Y. K., Chun, J. \& Lee, H. K. (2008). Maribacter arcticus sp. nov., isolated from Arctic marine sediment. Int J Syst Evol Microbiol 58, 1300-1303.

Choi, D. H., Kim, Y.-G., Hwang, C. Y., Yi, H., Chun, J. \& Cho, B. C. (2006). Tenacibaculum litoreum sp. nov., isolated from tidal flat sediment. Int J Syst Evol Microbiol 56, 635-640.

Cole, J. R., Chai, B., Farris, R. J., Wang, Q., Kulam-Syed-Mohideen, A. S., McGarrell, D. M., Bandela, A. M., Cardenas, E., Garrity, G. M. \& other authors (2007). The Ribosomal Database Project (RDP-II): introducing $m y R D P$ space and quality controlled public data. Nucleic Acids Res 35, D169-D172.

Englen, M. D. \& Kelley, L. C. (2000). A rapid DNA isolation procedure for the identification of Campylobacter jejuni by the polymerase chain reaction. Lett Appl Microbiol 31, 421-426.

Felsenstein, J. (1981). Evolutionary trees from DNA sequences: a maximum likelihood approach. J Mol Evol 17, 368-376.

Fitch, W. M. (1971). Toward defining the course of evolution: minimum change for a specific tree topology. Syst Zool 20, 406-416.
Graeber, I., Kaesler, I., Borchert, M. S., Dieckmann, R., Pape, T., Lurz, R., Nielsen, P., von Döhren, H., Michaelis, W. \& other authors (2008). Spongiibacter marinus gen. nov., sp. nov., a halophilic marine bacterium isolated from the boreal sponge Haliclona sp. 1. Int J Syst Evol Microbiol 58, 585-590.

Guillard, R. R. L. \& Ryther, J. H. (1962). Studies of marine planktonic diatoms. I. Cyclotella nana Hustedt and Detonula confervacea Cleve. Can J Microbiol 8, 229-239.

Hansen, G. H. \& Sørheim, R. (1991). Improved method for phenotypical characterization of marine bacteria. J Microbiol Methods 13, 231-241.

Jeon, Y.-S., Chung, H., Park, S., Hur, I., Lee, J.-H. \& Chun, J. (2005). jPHYDIT: a JAVA-based integrated environment for molecular phylogeny of ribosomal RNA sequences. Bioinformatics 21, 31713173.

Jukes, T. H. \& Cantor, C. R. (1969). Evolution of protein molecules. In Mammalian Protein Metabolism, vol. 3, pp. 21-132. Edited by H. N. Munro. New York: Academic Press.

Lane, D. J. (1991). 16S/23S rRNA sequencing. In Nucleic Acid Techniques in Bacterial Systematics, pp. 115-175. Edited by E. Stackebrandt \& M. Goodfellow. Chichester: Wiley.

Lemos, M. L., Toranzo, A. E. \& Barja, J. L. (1985). Modified medium for the oxidation-fermentation test in the identification of marine bacteria. Appl Environ Microbiol 49, 1541-1543.

Lyman, J. \& Fleming, R. H. (1940). Composition of sea water. J Mar Res 3, 134-146.

Manaia, C. M., Nogales, B. \& Nunes, O. C. (2003). Tepidiphilus margaritifer gen. nov., sp. nov., isolated from a thermophilic aerobic digester. Int J Syst Evol Microbiol 53, 1405-1410.

Marmur, J. (1961). A procedure for the isolation of deoxyribonucleic acid from microorganisms. J Mol Biol 3, 208-218.

Mesbah, M., Premachandran, U. \& Whitman, W. B. (1989). Precise measurement of the $\mathrm{G}+\mathrm{C}$ content of deoxyribonucleic acid by highperformance liquid chromatography. Int J Syst Bacteriol 39, 159-167.

Posada, D. \& Crandall, K. A. (1998). MODELTEST: testing the model of DNA substitution. Bioinformatics 14, 817-818.

Rosselló-Mora, R. \& Amann, R. (2001). The species concept for prokaryotes. FEMS Microbiol Rev 25, 39-67.

Saitou, N. \& Nei, M. (1987). The neighbor-joining method: a new method for reconstructing phylogenetic trees. Mol Biol Evol 4, 406425.

Skerman, V. B. D. (1967). A Guide to the Identification of the Genera of Bacteria, 2nd edn. Baltimore: Williams \& Wilkins.

Smibert, R. M. \& Krieg, N. R. (1994). Phenotypic characterization. In Methods for General and Molecular Bacteriology, pp. 607-654. Edited by P. Gerhardt, R. G. E. Murray, W. A. Wood \& N. R. Krieg. Washington, DC: American Society for Microbiology.

Swofford, D. L. (1998). PAUP ${ }^{*}$ - Phylogenetic analysis using parsimony, version 4. Sunderland, MA: Sinauer Associates.

Tamura, K., Dudley, J., Nei, M. \& Kumar, S. (2007). MEGA4: molecular evolutionary genetics analysis (MEGA) software version 4.0. Mol Biol Evol 24, 1596-1599.

Yumoto, I., Hirota, K., Nodasaka, Y., Yokota, Y., Hoshino, T. \& Nakajima, K. (2004). Alkalibacterium psychrotolerans sp. nov., a psychrotolerant obligate alkaliphile that reduces an indigo dye. Int $J$ Syst Evol Microbiol 54, 2379-2383. 